2021 • Summer - Yaz • Volume - Cilt: 12 • Issue - Sayı: 46

\title{
Decision Support Systems: A Content Analysis of Graduate Theses in Turkey
}

Hüseyin GÖKAL, İstanbul Esenyurt University, Vocational School, Department of Computer Technologies, Lecturer, huseyingokal@esenyurt.edu.tr (DD 0000-0001-5687-7715

Volkan CANTEMIR, İstanbul Esenyurt University, Vocational School, Department of Computer Technologies, Lecturer, volkancantemir@esenyurt.edu.tr, (DD 0000-0002-6632-8151

Ahmet ADALIER, Cyprus International University, School of Applied Sciences, Department of Management Information Systems, Assoc.Prof. Dr., aadalier@ciu.edu.tr, (DD 0000-0002-9947-3398

ABSTRACT

Keywords : Decision Support Systems, Graduate Theses, Descriptive Content Analysis, Technology, Higher Education

\section{Karar Destek Sistemleri: Türkiye’deki Lisansüstü Tezlerin Betimsel İçerik Analizi} $\ddot{O Z Z}$

Bu çalışma, Türkiye'de 1989-2020 yılları arasında yürütülen karar destek sistemlerine ilişkin lisansüstü tezlerinin betimsel bir analizini ve değgerlendirmesini yapmayı amaçlamaktadır. Araştırmada, nitel araştırma yöntemleri kullanılmış ve tezler betimsel içerik analizi tekniği ile analiz edilmiştir. YÖK ulusal tez merkezi veri tabanında kayıtlı ve erişilme izni olan 48 lisansüstü çalışma incelenmiştir. Tezler 
yayın tarihi, üniversite, enstitü, bölüm, yüksek lisans//doktora düzeyi, danışman unvanı, dili, araştırma yöntemi, araştırma alt alanına göre kodlanmıştır. Tezler incelendiğinde son 15 yılda bu konu ile ilgili 42 çalışma yapılarak yüksek oranda artış göstermiştir. Karar Destek Sistemleriyle ilgili birçok üniversitede çalışmalar yapılmış olup, Selçuk Üniversitesi lisansüstü çalışmasıyla konuya en fazla katkı sağlayan üniversitedir. Çalışmaların yarısı Fen Bilimleri Enstitüsünde yapılmış ve üniversitelerde üretilen çalışmalarm çoğu yüksek lisans tezlerinden oluşmuştur. Tez yöneticilerinin çoğu "Prof. Dr." ünvanlı öğretim üyeleridir. Çalışmaların çoğu Türkçe yazılmış ve en çok deneysel yöntem kullanılmıştır. Tezlerin çoğu işletme bölümündeki çalışmalardan üretilmiştir. Tezler başlica işletme ve çeore disiplinlerinde yapılmıştır. Tezler 7 enstitü ve 26 farklı bölümde yürütülmüştür. Bu çalışmanın bulguları, karar destek sistemleri alanında çalışmak isteyen diğer araştırmacilara yol gösterecektir.

\section{Anahtar : Karar Destek Sistemleri, Lisansüstü Tezler, Betimsel içerik Analizi, Teknoloji, Kelimeler Yükseköğretim}

\section{INTRODUCTION}

Information systems have become more significant to support managerial decisions in recent years. Companies' decisions involve the management and use of information systems and data interpretation from the business and its environment. The essential characteristic of a manager is her/his ability to make fast and correct decisions. Among the managers' duties, the most crucial task is to make the best decision in the shortest time possible. A good decisionmaking process can be achieved by producing accurate, UpToDate, and timely information. Today, managers have to comprehend their organisation's capabilities and uses of information significantly to comprehend budgeting financial resources (Pearlson, Saunders and Galletta, 2019).

Decisions are classified as unstructured, semi-structured, and structured. Unstructured decisions "are those in which the decision-maker must provide judgment, evaluation, and insight to solve the problem" (Laudon \& Laudon, 2020). Each of these decisions is novel, essential, and non-routine, and there is no well-understood or agreed-on procedure for making them. On the other hand, structured decisions "are repetitive and routine, and they comprise a definite procedure for handling them so that they do not have to be treated each time as if they were new" (Laudon \& Laudon, 2020). Many decisions have elements of both types of decisions and are classified as semi-structured decisions. In semi-structured decisions, only a part of the problem has a definite answer provided by an accepted procedure (Laudon \& Laudon, 2020). 
A decision support system (DSS) is "an information system at the organisation's management level that combines data and sophisticated analytical models or data analysis tools to support semi-structured and unstructured decision making" (Laudon \& Laudon, 2018). Gorry and Scott Morton, in 1971 first mentioned DSS, and it has been widely used in many applications (Gorry and Morton, 1971). DSS is intended to support decision-makers to assist and improve their decisions regarding the process and the outcome of their business activities (Laudon \& Laudon, 2020, Biswas, 2020). DSSs serve the middle and higher management, operations, and planning levels of an organisation. DSS do not replace the decision-maker or the manager; they are the systems that only assist and support the decisionmaker in their decision (Rainer, Prince, and Watson, 2017).

Information as a vital source of the development of competitive advantage is crucial for businesses to be managed. Thus, businesses have to accept this change and continuously renew themselves to compete with their rivals in rapidly developing competitive conditions. Otherwise, they are doomed to have difficulty competing with their rivals and disappear (Rainer, Prince and Watson, 2017). Increasing the opportunities of any business to gain the aforesaid competitive advantage is possible using DSS in critical decision-making conditions.

The use of DSS in supporting business process examples based on the literature are; higher education sector (Zhu, 2018), health (Belciug \& Gorunescu, 2020; Lakshmanaprabu, Mohanty, Krishnamoorthy, Uthayakumar, \& Shankar, 2019), tourism (Isoda, Hidaka, Matsuda, Suwa, \& Yasumoto, 2020), transportation (Sun, Dubey, White, \& Gokhale, 2019), environmental (Kharbat, \& Sultan, 2017), oil industry (Abu-Abed \& Khabarov, 2019), agricultures (Hafezalkotob, Hami-Dindar \& Rabie, 2018), fisheries and marine affairs (Hozairi \& Krisnafi,2017). This tendency suggests that multipurpose DSS applications support the decision-making process (Teniwut \& Hasyim, 2020).

Decision Support Systems as a fundamental topic needs to be handled with various branches of science. This study aimed to investigate academic work at the graduate level that has been done on the decision support system over the last 31 years in Turkey. A total of 48 Master's and Doctoral theses were analysed, and the findings are resented in this paper.

This study is significant as it examines the postgraduate studies conducted in the field of DSSs in Turkey. It provides descriptive information about the nature of the studies and offers recommendations for future studies on decision support systems.

\section{METHOD}

\subsection{Research Questions and the Design of the Study}

This study addresses the following research question and its sub-questions. 
How many graduate theses have been written on the Decision Support Systems over 31 years in Turkey?

1. How many theses have been written on DSS in various years in Turkey?

2. How many theses have been written on DSS in various universities in Turkey?

3. How many theses have been written on DSS in various institutes in Turkey?

4. How many theses have been written on DSS in various departments in Turkey?

5. How many masters' and doctorate degrees are there on DSS?

6. What are the academic titles of the supervisors who have supervised theses on DSS?

7. How many theses on DSS have been written in Turkish and English?

8. What are the research methodologies that researchers working on DSS followed?

9. How many sub-areas have been involved in research on DSS?

This study employed descriptive content analysis of the qualitative research approach. Content analysis is a process of summarising and reporting written data. The researcher reads, organises, and digitises the data per the codes, categories, and themes previously created (Dawson, 2019). Thus, researchers gained the opportunity to interpret data from the existing sources using the keywords in the searched studies. They were able to show the frequency of the importance of the topic under investigation.

\subsection{Population}

Purposive sampling was used as a sampling strategy. The population consists of theses and dissertations accessible from the YÖK's "National Thesis Centre." The first dissertation on decision support systems was published in 1989 in the National Thesis Centre. Therefore, the study's time frame was determined as from 1989 to 2020 to include all published theses accessible from the centre on DSS. Theses within the scope of the research were downloaded between 01.12 .2020 and 30.12.2020 by the researchers. 48 Theses, 32 of which were masters' theses, 15 were doctoral dissertations, and only one was a PhD thesis on medical speciality.

\subsection{Data Collection Procedure and Analysis}

During the data collection procedure, the keywords for the DSS concept were entered both in Turkish and English in the search engine as "karar destek sistemleri, decision support systems". 72 Theses were located in the National Thesis Centre, 48 of which were open to access (Appendix 1). All 48 theses with access permission within the field of decision support systems registered in the database of YÖK were included in the study. Out of 48 theses, 32 
were masters' theses, 15 were doctoral dissertations, and only one was a $\mathrm{PhD}$ thesis on medical speciality. 24 theses out of the initially available 72 were eliminated from the study because their full-texts were not accessible due to the access limits placed by the authors. The figure 1 shows the data collection procedure visually.

The theses were uploaded to the computer in PDF document format. The unit of analysis was identified as descriptive information regarding the nature of the graduate theses on DSS. Each thesis was assigned with numbers starting from 1 to 48 . The abstracts and full texts of 48 theses were read and analysed thoroughly. Nine codes for the analysis were identified. The codes are as follows: the year, the university, the institute, the department, the degree level, supervisors' academic title, language, the research methodology, and the research sub-area. Then, the frequency of each code was counted. The information on the frequency of the codes enabled the researcher to compare them. The comparison showed the focus of academic work regarding DSS over 31 years.

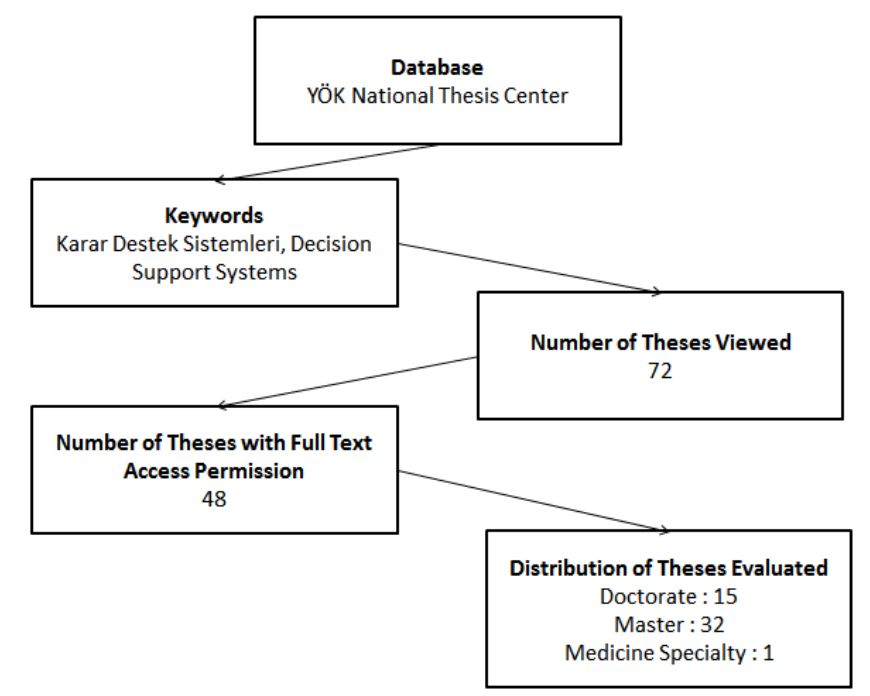

Figure 1: Data Collection Procedure

\section{FINDINGS}

In this section, the descriptive findings of the graduate theses on DSS written between 1989 and 2020 are presented. The graphs presented below involve descriptive information about the year, the university, the institute, the department, the degree level, supervisors' academic title, the theses' language, the research method, and the research sub-areas. 


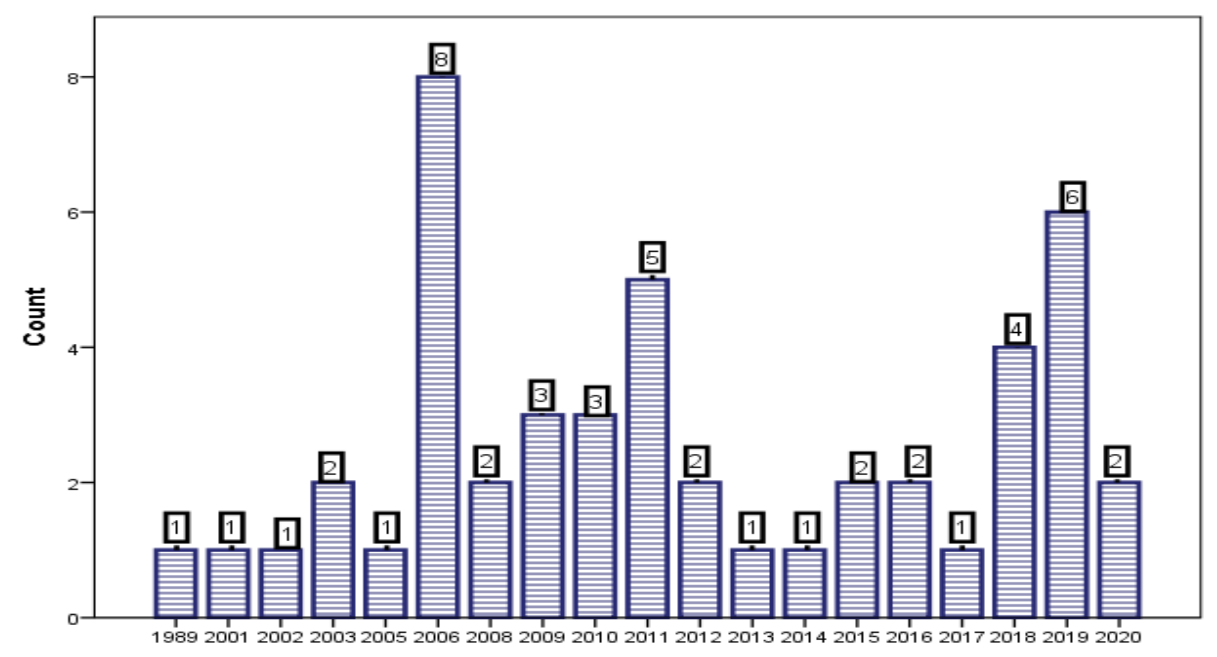

Figure 2: Graduate Theses According to Years

Figure 2 shows that there is a significant increase in the number of theses published since 1989. The first and only study in the field was carried out in 1989, and the second study was carried out 15 years later in 2001. The years when DSS was the most popular research topic among the graduate students were 2006, 2011 and 2019. Eight studies were conducted in 2006. They form $16.67 \%$ of the total studies over the 31 years. There were six $(12.50 \%)$ studies in 2019 and five (10.42\%) in 2011.

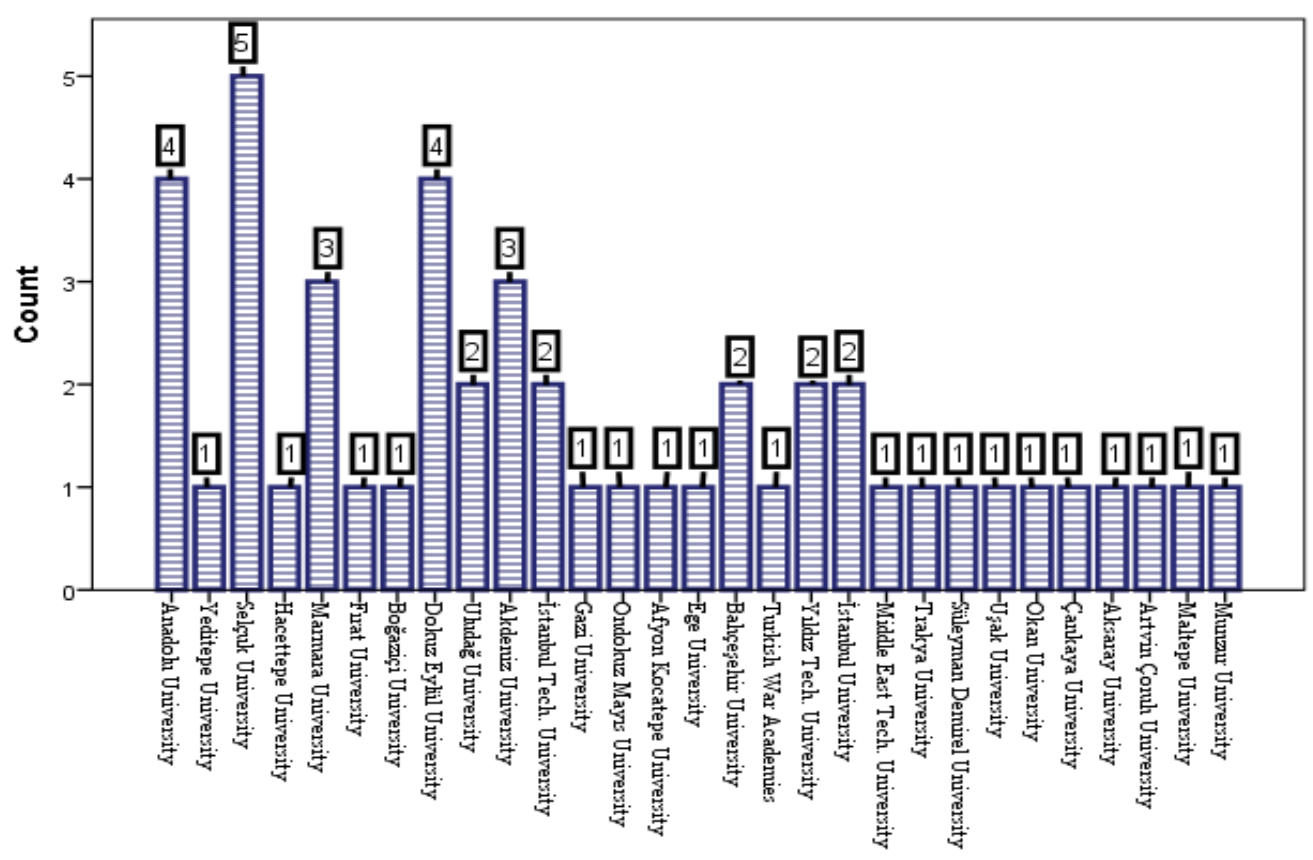

Figure 3: Graduate Theses According to Universities 
Figure 3 represents the universities where graduate students wrote their theses on DSS. According to the findings, Selçuk University is in the leader position with the most studies on DSS with 5 (10.42\%) theses. Anadolu and Dokuz Eylül Universities are the second with 4 $(8.33 \%)$ theses in each. Hacettepe and Akdeniz Universities follow with three theses. In other universities, only one or two theses were produced.

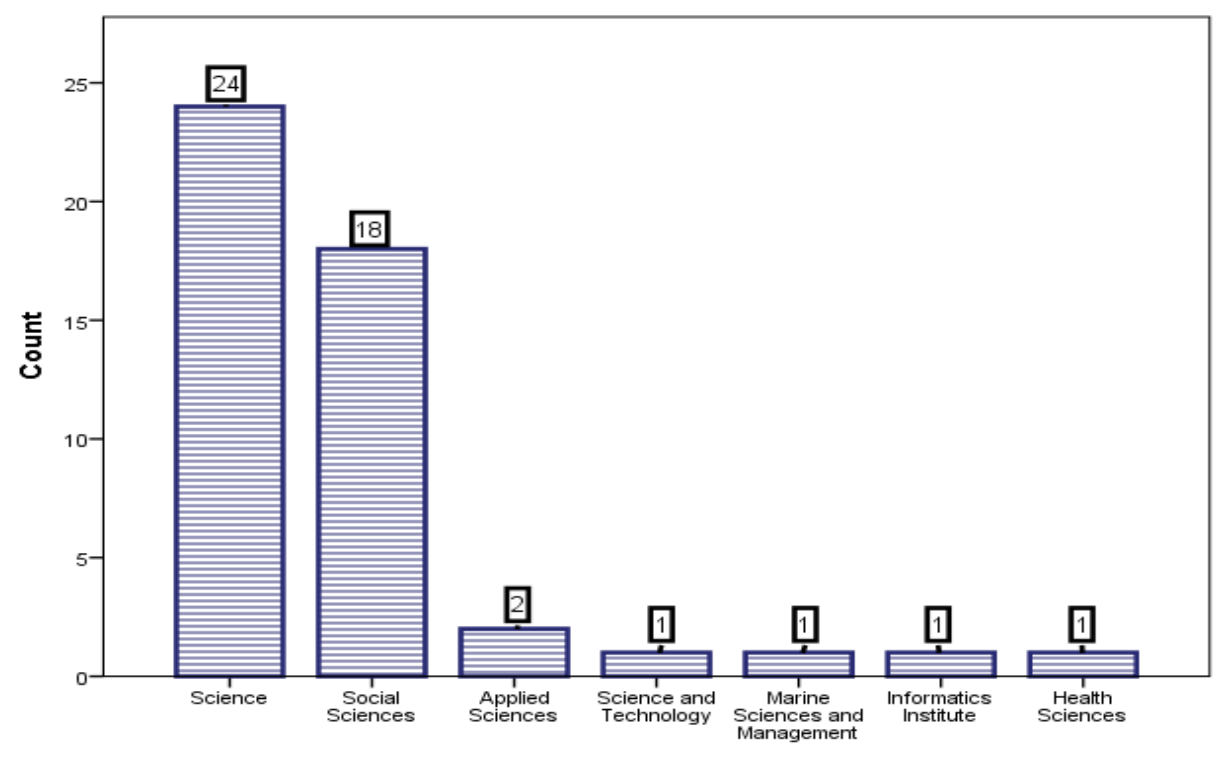

Figure 4: Graduate Theses According to Institutes

According to Figure 4, the Institute of Science has been determined as the institute with the highest number of studies. Half of the theses on DDS were conducted under this institute. The next was the social sciences institute with 18 (37.50\%) theses. A total number of 48 studies were conducted under seven institutes, including Institutes of science, social sciences, applied sciences, science and technology, marine sciences and management, informatics, and the health sciences. As the numbers of theses in the institutes of science and social sciences are high, a question arises concerning the lack of theses in the other institutes. 


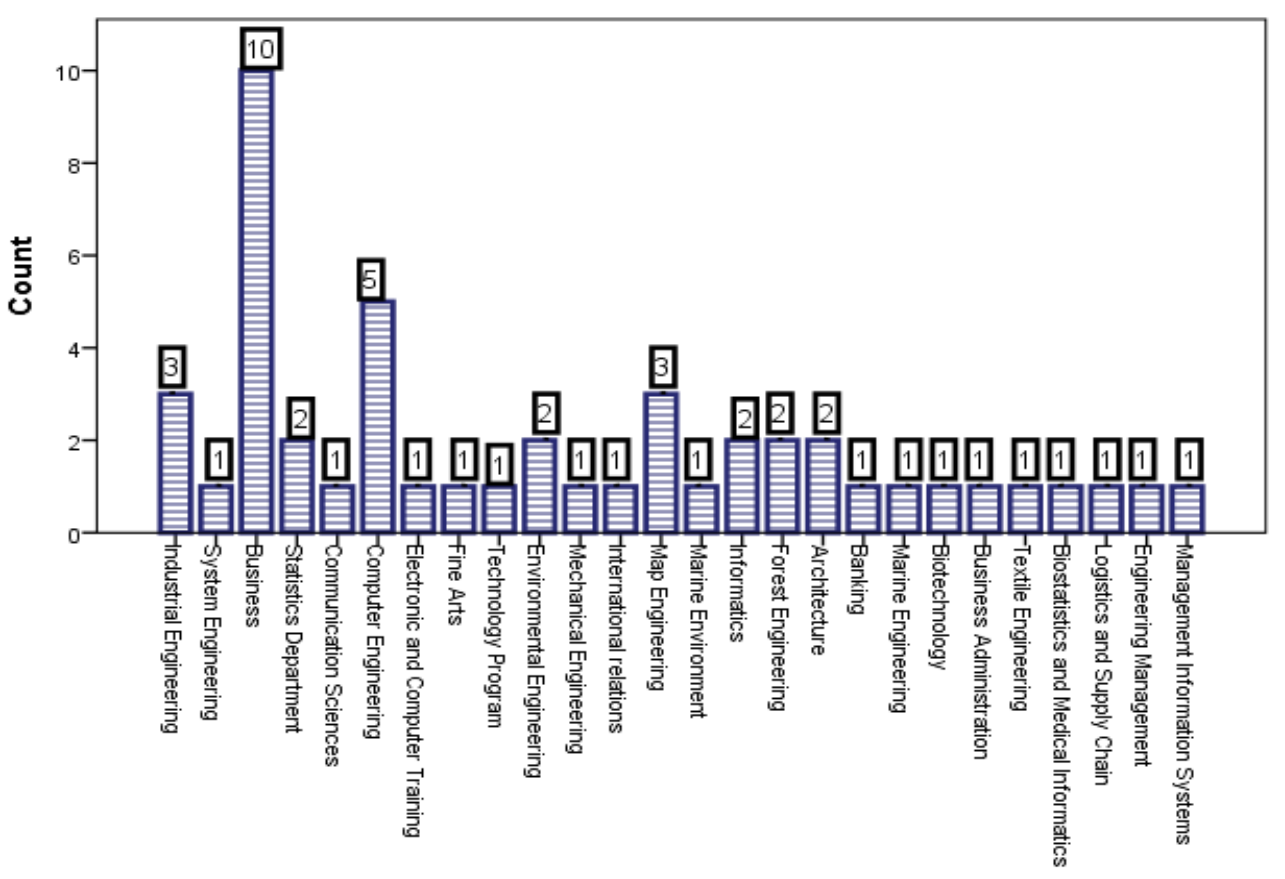

Figure 5: Graduate Theses Witten According to Departments

A total of 48 thesis studies were conducted in 26 various departments, as shown in Figure 5. The business department is one of the departments that predominantly produce theses in DSS. This is not an extraordinary result as DSS aims to help managers and businesses in decision-making. Business departments had ten theses $(20.83 \%)$ in DSS. The computer engineering departments carried out $5(10.42 \%)$ studies only.

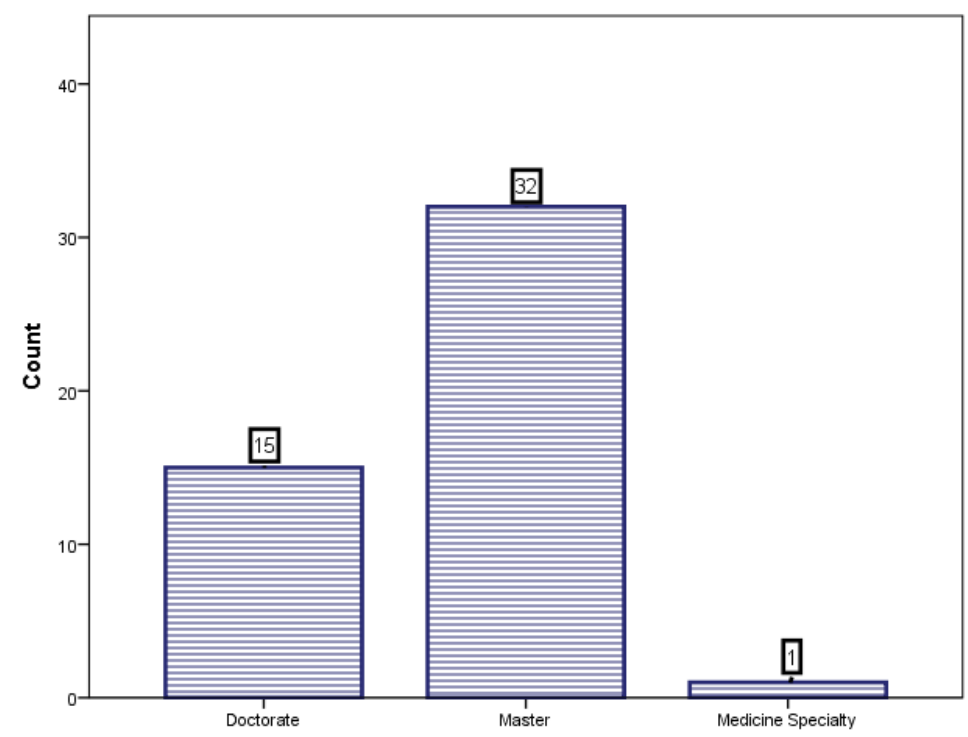

Figure 6: Graduate Theses According to Degree Levels 
As shown in Figure 6, regarding the degree levels of theses produced in universities on DSS, 32 (66.67\%) were the master's theses, 15 of them were doctoral dissertations (31.25\%), and only a single (2.08\%) PhD dissertation in medical specialty was carried out according to YÖK's "National Thesis Centre".

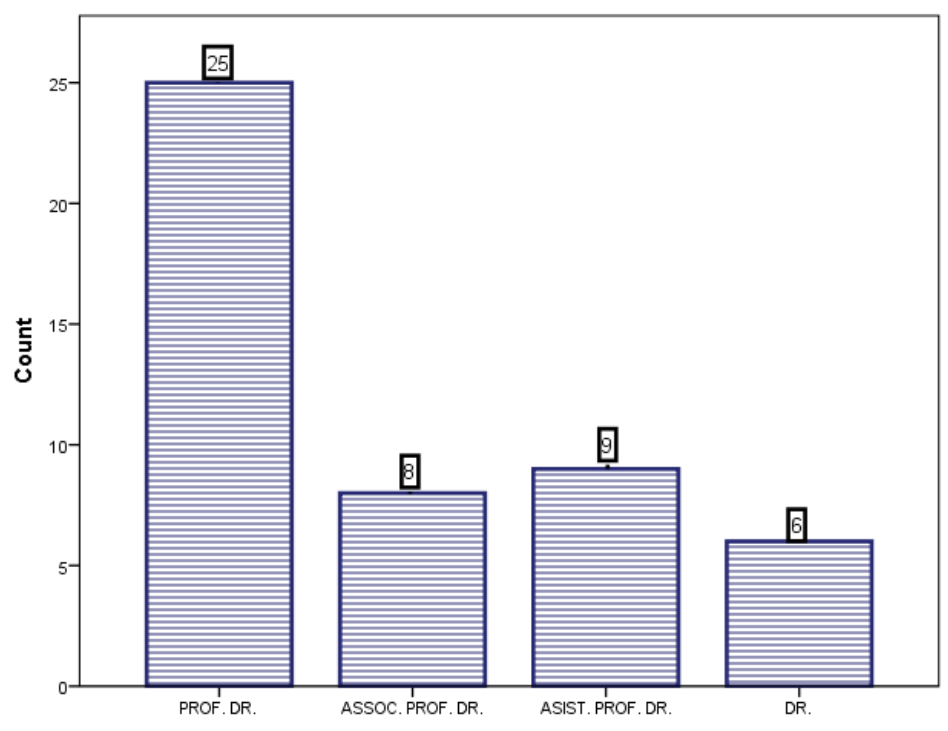

Figure 7: Graduate Theses According to Advisors' Academic Titles

As shown in figure 7, 25 (52.08\%) of the theses were supervised by "Prof. Dr." titled faculty members. In other words, more than half of these thesis studies are supervised by "Prof. Dr." titled faculty members. Faculty members with the titles of "Assoc. Prof. Dr." supervised 9 $(18.75 \%)$ theses. The rest of the $8(16.67 \%)$ theses were supervised by "Assist. Prof. Dr.", and 6 (12.50\%) were supervised by "Dr." titled faculty members.

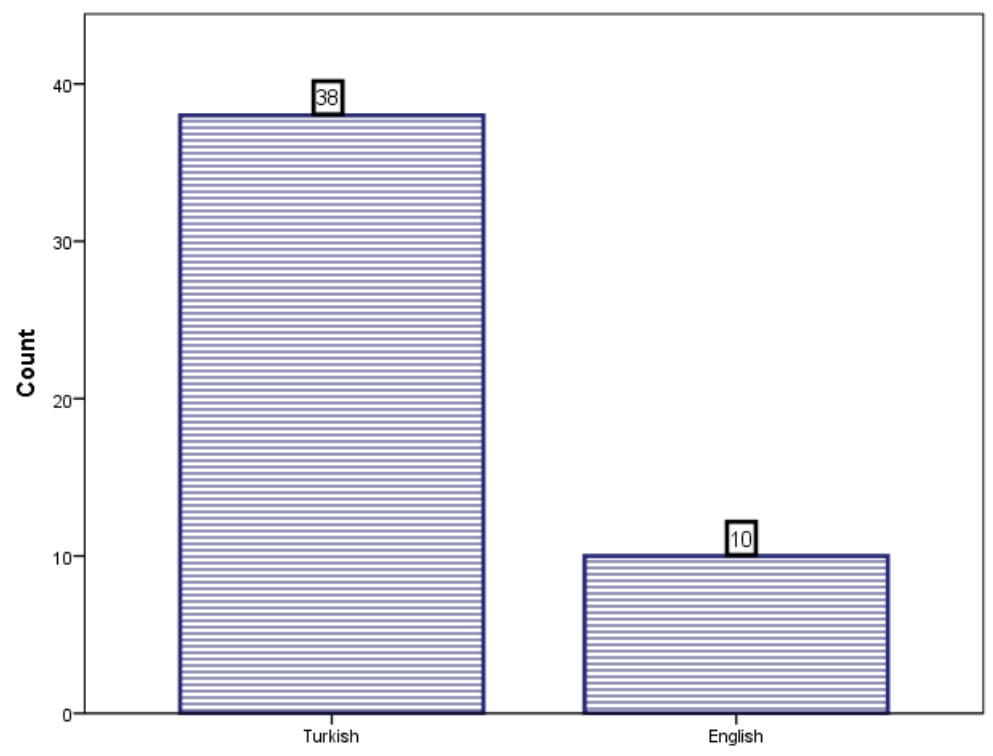

Figure 8: Graduate Theses According to Languages 


\section{AJIT-e Bilişim Teknolojileri Online Dergisi \\ Academic Journal of Information Tecnology}

2021 Summer/Yaz - Cilt/Vol: 12 - Sayı/Issue: 46

doi) 10.5824/ajite.2021.03.001.x

As seen from figure 8, 38 (79.17\%) of the theses were written in Turkish, and only 10 $(20.83 \%)$ were written in English.

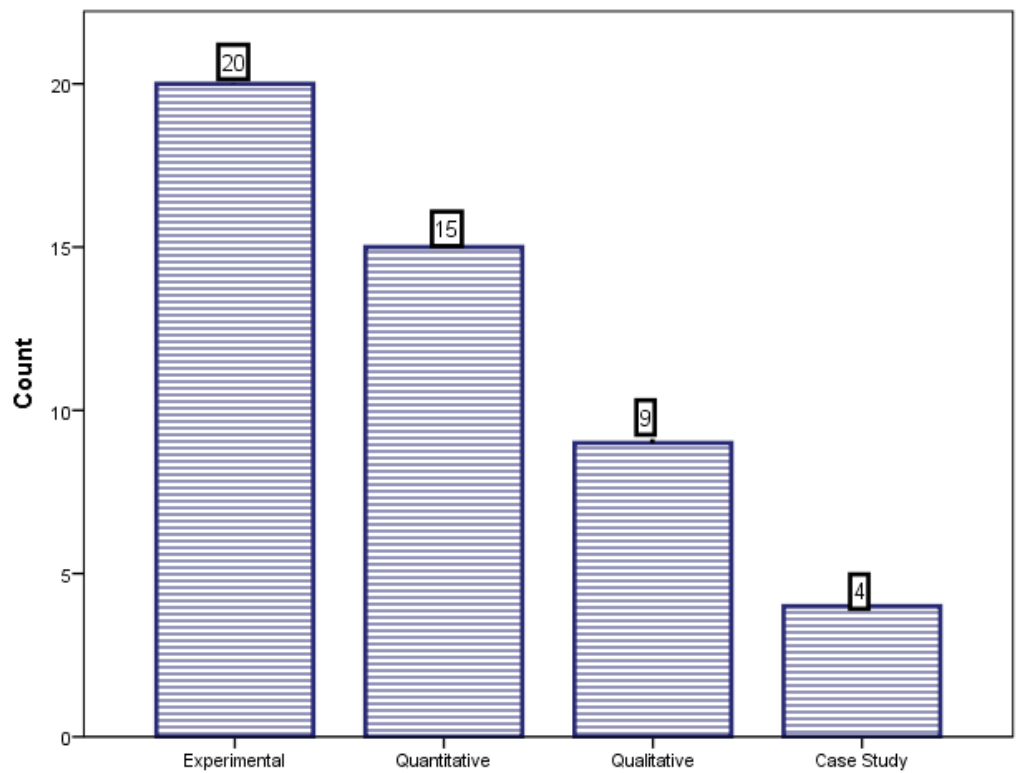

Figure 9: Graduate Theses According to Research Methodology

As shown in Figure 9, experimental studies constitute the maximum with 20 (41.67\%) studies, 15 (31.25\%) studies were carried out quantitatively, and 9 (18.75\%) were conducted qualitatively. Only 4 (8.33\%) of the theses followed a case study design.

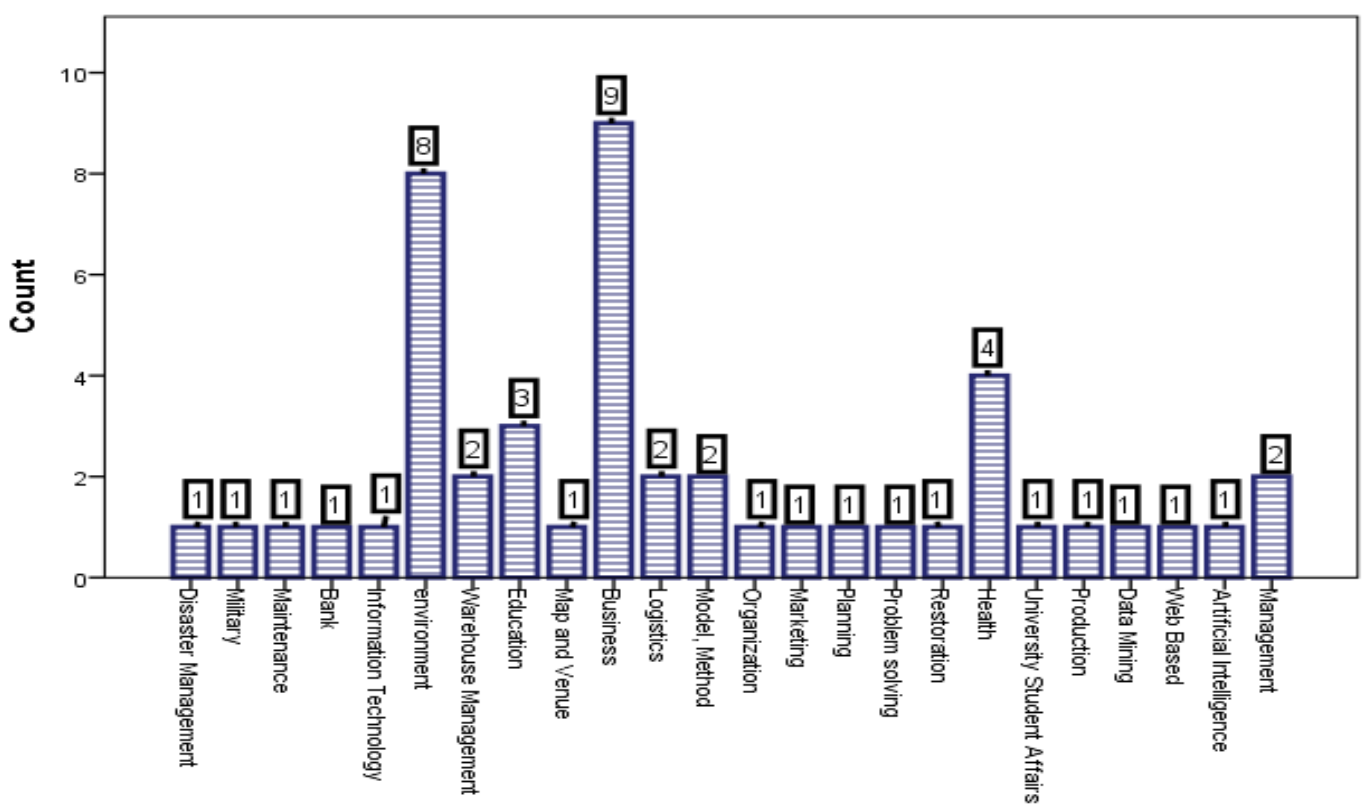

Figure 10: Graduate Theses According to Research Sub-areas 
As shown in Figure 10, most studies on DSS were related to business. 9 Studies (18.75\%) were conducted in business. 8 (16.67\%) studies were carried out in environmental studies. A total of 31 studies were conducted in the sub-areas of banking, health, military, logistics, information technology, maintenance, disaster management, warehouse management, map space, model and method, organization, marketing, planning, problem-solving, restoration, student affairs, production, data mining, web base, artificial intelligence, and management.

\section{DISCUSSION AND CONCLUSION}

According to the results, graduate studies on DSS have increased in the last 15 years; 42 studies have been conducted in total. There has been a significant increase in the number of theses published since 2001. The first and only study in the field was carried out in 1989, and the subsequent study was conducted 15 years later, in 2001. Most of the studies were conducted in 2006, followed by 2019 and 2011. Selçuk University ranks first with the most studies on DSS. Half of the studies were carried out in the Institute of Science. Most of the work that was produced in the universities was master's theses. Most supervisors were "Prof. Dr." titled faculty members. Most of the theses were written in Turkish, and most experimental studies were conducted. The business administration department produced most of the theses on DSS. Business and environment studies were the primary disciplines that produced theses. Initially, more studies were expected to be found in other areas such as marketing and student affairs in higher education. In such areas, DSS could ensure a competitive advantage.

Inevitably DSS is a tool for businesses to improve as management gets the opportunity to develop their organizations by making appropriate decisions with the support of the system. Discovering that there were only nine studies over 31 years in the business field was surprising.

According to the results of this study, the number of master's or doctorate thesis are very few in healthcare/medicine subjects in Turkey. In the last few years, substantial progress has been made in artificial intelligence field and the machine learning context. Features provided in practical applications range from supporting the user while making decisions, e.g., in a recommender system, to making decisions fully autonomously. Applying machine language algorithms to new large datasets can expose novel tendencies and relationships that may have practical effects for clinical practice in medicine/healthcare decision support systems (Brusko, Kolcun, \& Wang, 2018). Researchers have studied the application of machine language methods in healthcare decision support systems and have demonstrated the significant impact of machine language in making enhancements to healthcare safety, quality, and DSSs (Buchlak, Esmaili, Leveque, Farrokhi, Bennett, Piccardi, \& Sethi, 2019; Miotto, Wang, Jiang, \& Dudley, 2018; Liang, Zhang, Huang, \& Hu, 2014). Therefore, the universities should focus on doing more research in healthcare subjects, either master or doctorate level. 
Arnott \& Pervan (2016) indicated in their research that; using information technologybased systems to support managers and senior personnel's decision-making activities has been a significant feature of information system (IS) research and practice since the IS discipline appeared in the 1960s and 1970s. In the future, this trend will continue as especially business intelligence is presently rated as the most vital information technology subject for CIOs worldwide, and DSS research is currently over $10 \%$ of the IS discipline (Arnott \& Pervan, 2016). The decision support system is an important research topic for many various disciplines and departments. Many departments in various disciplines worked on this subject. They revealed the importance of decision-making and decision support systems, regardless of discipline, program, and faculty. Remarkably, most of the studies conducted were experimental.

Today, the increase in complexity of machine learning techniques based on deep learning provides enlightenments for scientists to comprehend the consequences of these methods is appealing essential in decision support systems.

\subsection{Recommendations}

Future research could concentrate on the studies published in internationally indexed journals. Comparisons concerning the methodology, field of studies, and studies' contributions might be analysed. Postgraduate students, namely masters and doctorate, could be encouraged to review DSS studies in different countries and write comparative studies. Such studies could contribute to both practitioners and decision-makers. Moreover, the research scope can be expanded by examining the articles on the subject at the national and international levels. More studies can be written jointly by various disciplines. As mentioned earlier, the new developments in the world lead all companies and countries to concentrate more on the decision making as technology is the main driving force of the developments and competitive advantage. Therefore, studying DSS in the fields such as transportation, higher education, and service industries is necessary.

\subsection{Limitations}

This study is limited to postgraduate studies, which could be accessed from the Thesis Documentation Centre System of Higher Education Council, Turkey. Thus, the results of this study are generalizable within the context of Turkey. 


\section{REFERENCES}

Abu-Abed, T., \& Khabarov, A. (2019). Supplies of Oil and Gas Extracting Industry and Intelligent Decision Support System. Dilemas contemporáneos: Educación, Política y Valores, 6.

Arnott, D., \& Pervan, G. (2016). A critical analysis of decision support systems research revisited: the rise of design science. In Enacting Research Methods in Information Systems (pp. 43-103). Palgrave Macmillan, Cham.

Belciug, S., \& Gorunescu, F. (2020). How can intelligent decision support systems help the medical research? In Intelligent Decision Support Systems - A Journey to Smarter Healthcare. (pp. 71-102). Springer, Cham.

Biswas, J. (2020). Management information systems. $16^{\text {th }}$ Edition. SAGE:Texts.

Brusko, G. D., Kolcun, J. P. G., \& Wang, M. Y. (2018). Machine-learning models: the future of predictive analytics in neurosurgery. Neurosurgery, 83(1), E3-E4.

Buchlak, Q. D., Esmaili, N., Leveque, J. C., Farrokhi, F., Bennett, C., Piccardi, M., \& Sethi, R. K. (2019). Machine learning applications to clinical decision support in neurosurgery: an artificial intelligence augmented systematic review. Neurosurgical review, 1-19.

Gorry, G.A. and Scott, Morton, M.S. (1971) A Framework for Management Information Systems. Sloan Management Review. 13 (1), 55-70.

Hafezalkotob, A., Hami-Dindar, A., Rabie, N., \& Hafezalkotob, A. (2018). A decision support system for agricultural machines and equipment selection: A case study on olive harvester machines. Computers and Electronics in Agriculture, 148 (2018), 207-216.

Hozairi, H., \& Krisnafi, Y. (2017). Decision support system determination of main work unit in WPP711 using Fuzzy TOPSIS. Knowledge Engineering and Data Science, 1(1), 8-19.

Isoda, S., Hidaka, M., Matsuda, Y., Suwa, H., \& Yasumoto, K. (2020, November). User decision support system for on-site tourism navigation on smartphone: demo abstract. In Proceedings of the 18th Conference on Embedded Networked Sensor Systems (pp. 641-642).

Kharbat, F. F., \& Sultan, J. A. A. (2017). Environmental decision support systems: a literature review. Empirical Studies on Economics of Innovation, Public Economics and Management, (pp. 211-223). Springer, Cham.

Lakshmanaprabu, S. K., Mohanty, S. N., Krishnamoorthy, S., Uthayakumar, J., \& Shankar, K. (2019). Online clinical decision support system using optimal deep neural networks. Applied Soft Computing, 81(2019):105487.

Laudon, K. C., and Laudon, J. P. (2018). Essentials of Management information systems. $13^{\text {th }}$ Edition. Pearson.

Laudon, K. C., and Laudon, J. P. (2020). Management information systems: Managing the digital firm. $16^{\text {th }}$ Edition. Pearson. 


\section{AJIT-e Bilişim Teknolojileri Online Dergisi \\ Academic Journal of Information Tecnology}

2021 Summer/Yaz - Cilt/Vol: 12 - Sayı/Issue: 46

10.5824/ajite.2021.03.001.x

Liang, Z., Zhang, G., Huang, J. X., \& Hu, Q. V. (2014, November). Deep learning for healthcare decision making with EMRs. In 2014 IEEE International Conference on Bioinformatics and Biomedicine (BIBM) (pp. 556-559). IEEE.

Miotto, R., Wang, F., Wang, S., Jiang, X., \& Dudley, J. T. (2018). Deep learning for healthcare: review, opportunities and challenges. Briefings in bioinformatics, 19(6), 1236-1246.

Pearlson, K., E., Saunders, C., S. and Galletta, D.,F. (2019). Managing and Using Information Systems: A Strategic Approach. Seventh Edition. USA: Wiley.

Rainer, K., Prince, B., and Watson, H., J. (2017). Management information systems. $4^{\text {th }}$ Edition. Wiley.

Sun, F., Dubey, A., White, J., \& Gokhale, A. (2019). Transit-hub: A smart public transportation decision support system with multi-timescale analytical services. Cluster Computing, 22(1), 2239-2254.

Teniwut, W., \& Hasyim, C. (2020). Decision support system in supply chain: A systematic literature review. Uncertain Supply Chain Management, 8(1), 131-148.

Zhu, Y. (2018). A Data Driven Educational Decision Support System. International Journal of Emerging Technologies in Learning (iJET), 13(11), 4-16.

Appendix 1. Theses Table

\begin{tabular}{|c|c|c|c|c|c|}
\hline YYear & Title of Thesis & Author & University & Institute & $\begin{array}{c}\text { Master/ } \\
\text { Doctorate/ } \\
\text { Medicine S. }\end{array}$ \\
\hline 1989 & $\begin{array}{l}\text { Decision Support Systems and an } \\
\text { Application in Student Affairs }\end{array}$ & $\begin{array}{l}\text { M. Emin } \\
\text { MUTLU }\end{array}$ & $\begin{array}{l}\text { Anadolu } \\
\text { University }\end{array}$ & Science & Master \\
\hline 2001 & $\begin{array}{l}\text { Group Decision Support Systems for } \\
\text { Supply Chain Management }\end{array}$ & $\begin{array}{c}\text { Şener } \\
\text { ÇETINBAŞ }\end{array}$ & $\begin{array}{l}\text { Yeditepe } \\
\text { University }\end{array}$ & Science & Master \\
\hline 2003 & $\begin{array}{l}\text { Risk Analysis and Decision Support } \\
\text { Systems in Evaluation of Investment } \\
\text { Projects }\end{array}$ & $\begin{array}{l}\text { Muhammet } \\
\text { BEZİRCi }\end{array}$ & $\begin{array}{l}\text { Selçuk } \\
\text { University }\end{array}$ & $\begin{array}{c}\text { Social } \\
\text { Sciences }\end{array}$ & Doctorate \\
\hline 2002 & $\begin{array}{l}\text { Decision Support Systems: The Effect of } \\
\text { Self Effort to Academic Success in } \\
\text { Learning Computer Softwares }\end{array}$ & $\begin{array}{l}\text { Semra } \\
\text { ERPOLAT }\end{array}$ & $\begin{array}{l}\text { Hacettepe } \\
\text { University }\end{array}$ & Science & Medicine S. \\
\hline 2003 & $\begin{array}{c}\text { A Research on Organizational Decision } \\
\text { Support Systems and the Application of } \\
\text { Information Systems in Organisational } \\
\text { Decisions } \\
\end{array}$ & Erhan AKYAZI & $\begin{array}{l}\text { Marmara } \\
\text { University }\end{array}$ & $\begin{array}{c}\text { Social } \\
\text { Sciences }\end{array}$ & Doctorate \\
\hline 2006 & $\begin{array}{c}\text { Using Olap Tools on Web Based Decision } \\
\text { Support Systems }\end{array}$ & Aysan ALPAT & $\begin{array}{l}\text { Anadolu } \\
\text { University }\end{array}$ & Science & Master \\
\hline 2006 & $\begin{array}{l}\text { Decision Support Systems Based on } \\
\text { Pattern Recognition for Evaluating of } \\
\text { Histopathologic Images }\end{array}$ & $\begin{array}{l}\text { Suat } \\
\text { TORAMAN }\end{array}$ & $\begin{array}{c}\text { Firat } \\
\text { University }\end{array}$ & Science & Master \\
\hline 2005 & $\begin{array}{c}\text { Decision Support Systems in Main } \\
\text { Production Planning in a Facility That is } \\
\text { Used and Produced Without Stock } \\
\text { Application }\end{array}$ & $\begin{array}{l}\text { Özlem } \\
\text { HASGÜL }\end{array}$ & $\begin{array}{l}\text { Anadolu } \\
\text { University }\end{array}$ & $\begin{array}{l}\text { Social } \\
\text { Sciences }\end{array}$ & Master \\
\hline
\end{tabular}




\begin{tabular}{|c|c|c|c|c|c|}
\hline 2006 & $\begin{array}{l}\text { A Framework for Integrating Knowledge } \\
\text { Management and Decision Support } \\
\text { Systems by Using Knowledge Discovery } \\
\text { Techniques: A Case Study Forecasting } \\
\text { Financial Time Series }\end{array}$ & $\begin{array}{l}\text { Zarife Gonca } \\
\text { GÜLSER }\end{array}$ & $\begin{array}{l}\text { Boğaziçi } \\
\text { University }\end{array}$ & $\begin{array}{c}\text { Social } \\
\text { Sciences }\end{array}$ & Master \\
\hline 2006 & $\begin{array}{l}\text { Implementation of Decision Support } \\
\text { Systems for Landfill Sites }\end{array}$ & $\begin{array}{c}\text { Hasan } \\
\text { SARPTAŞ }\end{array}$ & $\begin{array}{c}\text { Dokuz Eylül } \\
\text { University }\end{array}$ & $\begin{array}{l}\text { Applied } \\
\text { Sciences }\end{array}$ & Doctorate \\
\hline 2006 & $\begin{array}{c}\text { Importance of Marketing Decision } \\
\text { Support Systems in Marketing } \\
\text { Information System and Developing } \\
\text { Example Marketing Information Systems } \\
\text { in Migros }\end{array}$ & $\begin{array}{l}\text { Banu } \\
\text { NAHARCI }\end{array}$ & $\begin{array}{l}\text { Uludağ } \\
\text { University }\end{array}$ & $\begin{array}{c}\text { Social } \\
\text { Sciences }\end{array}$ & Master \\
\hline 2006 & $\begin{array}{c}\text { In Employee Selection and Evaluation of } \\
\text { Performance Decision Support Systems: } \\
\text { an Application at Antalya Textile } \\
\text { Management }\end{array}$ & Serdar URHAN & $\begin{array}{l}\text { Akdeniz } \\
\text { University }\end{array}$ & $\begin{array}{c}\text { Social } \\
\text { Sciences }\end{array}$ & Master \\
\hline 2006 & $\begin{array}{l}\text { The Role of Decision Support Systems in } \\
\text { the Decision-Making Process (An } \\
\text { Investigation of A Business Operating in } \\
\text { the Automotive Sector) }\end{array}$ & Levent ÇELİK & $\begin{array}{l}\text { Marmara } \\
\text { University }\end{array}$ & $\begin{array}{c}\text { Social } \\
\text { Sciences }\end{array}$ & Master \\
\hline 2006 & $\begin{array}{l}\text { Web-Based Group Decision Support } \\
\text { Systems in Defence Technologies }\end{array}$ & $\begin{array}{l}\text { Yavuz } \\
\text { GÖSTERİŞLI }\end{array}$ & $\begin{array}{c}\text { İstanbul } \\
\text { Technical } \\
\text { University }\end{array}$ & $\begin{array}{l}\text { Science and } \\
\text { Technology }\end{array}$ & Master \\
\hline 2008 & $\begin{array}{c}\text { Decision Support Systems in Integrated } \\
\text { Logistic Management and an Application } \\
\text { Software }\end{array}$ & $\begin{array}{l}\text { Gökhan } \\
\text { ŞENOL }\end{array}$ & $\begin{array}{l}\text { Uludağ } \\
\text { University }\end{array}$ & $\begin{array}{c}\text { Social } \\
\text { Sciences }\end{array}$ & Doctorate \\
\hline 2008 & $\begin{array}{c}\text { Control Systems Based on Decision } \\
\text { Support Systems in Disaster Management }\end{array}$ & \begin{tabular}{|c|} 
Barış \\
KALAYCIOĞL \\
$U$
\end{tabular} & $\begin{array}{l}\text { Gazi } \\
\text { University }\end{array}$ & Science & Master \\
\hline 2009 & $\begin{array}{l}\text { Resolving of The Lot-Sizing Problems in } \\
\text { the Material Requirement Planning } \\
\text { Process By Decision Support Systems }\end{array}$ & \begin{tabular}{|c|} 
Alihan \\
GÜZELDÜLGE \\
$\mathrm{R}$
\end{tabular} & $\begin{array}{l}\text { Selçuk } \\
\text { University }\end{array}$ & Science & Master \\
\hline 2009 & $\begin{array}{c}\text { Decisions Based on Information } \\
\text { Technology and Implication of Group } \\
\text { Decision Support Systems }\end{array}$ & $\begin{array}{c}\text { Didem } \\
\text { PAŞAOĞLU } \\
\text { HAMŞIOĞLU }\end{array}$ & $\begin{array}{l}\text { Anadolu } \\
\text { University }\end{array}$ & $\begin{array}{c}\text { Social } \\
\text { Sciences }\end{array}$ & Doctorate \\
\hline 2009 & $\begin{array}{c}\text { Usage of Decision Support Systems in } \\
\text { Management of Perishable Inventory and } \\
\text { Product Versus User Discordance } \\
\text { Problems in Blood Centers } \\
\end{array}$ & $\begin{array}{l}\text { Ahmet Haluk } \\
\text { ÇífTÇİ }\end{array}$ & $\begin{array}{l}\text { Dokuz Eylül } \\
\text { University }\end{array}$ & $\begin{array}{c}\text { Social } \\
\text { Sciences }\end{array}$ & Doctorate \\
\hline 2011 & $\begin{array}{c}\text { Development of Strategies For Planning } \\
\text { Water Basins Through Decision Support } \\
\text { Systems, Implementation of These } \\
\text { Strategies and Environmental Risk } \\
\text { Evaluation } \\
\end{array}$ & $\begin{array}{c}\text { Eda } \\
\text { ÖZBAYRAK }\end{array}$ & $\begin{array}{l}\text { Ondokuz } \\
\text { Mayıs } \\
\text { University }\end{array}$ & Science & Doctorate \\
\hline 2010 & $\begin{array}{c}\text { Application of Decision Support System } \\
\text { on Vehicle Management }\end{array}$ & $\begin{array}{c}\text { Serhat } \\
\text { DÜZAĞAÇ }\end{array}$ & $\begin{array}{c}\text { Afyon } \\
\text { Kocatepe } \\
\text { University } \\
\end{array}$ & Science & Master \\
\hline 2010 & $\begin{array}{l}\text { Design and Implementation of Hybrid } \\
\text { Intelligent Decision Support Systems }\end{array}$ & Serkan BALLI & $\begin{array}{c}\text { Ege } \\
\text { University }\end{array}$ & Science & Doctorate \\
\hline 2011 & $\begin{array}{c}\text { Warehouse Modelling and Verification } \\
\text { For Decision Support System: } \\
\text { Transportation System }\end{array}$ & Mert SUN & $\begin{array}{l}\text { Bahçeşehir } \\
\text { University }\end{array}$ & $\begin{array}{l}\text { Applied } \\
\text { Sciences }\end{array}$ & Master \\
\hline 2011 & $\begin{array}{l}\text { Compensation of Decision Support } \\
\text { Systems Usage and Turkey Between }\end{array}$ & $\begin{array}{l}\text { Muhammed } \\
\text { ÖZTOPRAK }\end{array}$ & $\begin{array}{c}\text { Turkish } \\
\text { General Staff }\end{array}$ & $\begin{array}{c}\text { Social } \\
\text { Sciences }\end{array}$ & Master \\
\hline
\end{tabular}


AJIT-e Bilişim Teknolojileri Online Dergisi

Academic Journal of Information Tecnology

2021 Summer/Yaz -Cilt/Vol: 12 - Sayı/Issue: 46

doi) 10.5824/ajite.2021.03.001.x

\begin{tabular}{|c|c|c|c|c|c|}
\hline & $\begin{array}{l}\text { 2005-2010 and With the Help of Israel's } \\
\text { Strategic Decision Module Review }\end{array}$ & & $\begin{array}{c}\text { War } \\
\text { Academies } \\
\text { Presidency }\end{array}$ & & \\
\hline 2010 & $\begin{array}{c}\text { Real Estate Valuation by Using } \\
\text { Multicriteria Decision Support System } \\
\text { (Analytic Hierarchy Process) and Ratio } \\
\text { Study }\end{array}$ & $\begin{array}{l}\text { Ahmet } \\
\text { YILMAZ }\end{array}$ & $\begin{array}{l}\text { Yıldız } \\
\text { Technical } \\
\text { University }\end{array}$ & Science & Master \\
\hline 2011 & $\begin{array}{l}\text { Establishing and Application of Spatial } \\
\text { Decision Support Systems For Land } \\
\text { Consolidation Projects }\end{array}$ & Mevlüt UYAN & $\begin{array}{l}\text { Selçuk } \\
\text { University }\end{array}$ & Science & Doctorate \\
\hline 2011 & $\begin{array}{c}\text { Marine Biological Diversity Assessment } \\
\text { For Marine Conservation Planning in } \\
\text { Antalya-Kas Using Decision Support } \\
\text { Systems }\end{array}$ & Volkan DEMIR & $\begin{array}{l}\text { İstanbul } \\
\text { University }\end{array}$ & $\begin{array}{l}\text { Marine } \\
\text { Sciences } \\
\text { and } \\
\text { Managemen } \\
\mathrm{t}\end{array}$ & Doctorate \\
\hline 2012 & $\begin{array}{l}\text { Predicting the Disease of Alzheimer (Ad) } \\
\text { With Snp Biomarkers and Clinical Data } \\
\text { Based Decision Support System Using } \\
\text { Data Mining Classification Approaches }\end{array}$ & $\begin{array}{c}\text { Onur } \\
\text { ERDOĞAN }\end{array}$ & $\begin{array}{l}\text { Ortadoğu } \\
\text { Technical } \\
\text { University }\end{array}$ & $\begin{array}{l}\text { Informatics } \\
\text { Institute }\end{array}$ & Master \\
\hline 2012 & $\begin{array}{c}\text { Applying Decision Support Systems to A } \\
\text { Case Study }\end{array}$ & $\begin{array}{c}\text { Nazan } \\
\text { DEMIRCİ }\end{array}$ & $\begin{array}{c}\text { Trakya } \\
\text { Universtiy }\end{array}$ & Science & Master \\
\hline 2013 & $\begin{array}{l}\text { Forest Fires Organization and Decision } \\
\text { Support Systems }\end{array}$ & $\begin{array}{l}\text { Emine Seda } \\
\text { YILDIZLI }\end{array}$ & $\begin{array}{l}\text { Süleyman } \\
\text { Demirel } \\
\text { University }\end{array}$ & Science & Master \\
\hline 2014 & $\begin{array}{c}\text { A Research About the Awareness of } \\
\text { Decision Support Systems in Sme in } \\
\text { Chosen Provinces of Aegean Region in } \\
\text { Turkey }\end{array}$ & $\begin{array}{l}\text { Hasbiye } \\
\text { DİZMAN }\end{array}$ & $\begin{array}{c}\text { Uşak } \\
\text { University }\end{array}$ & $\begin{array}{l}\text { Social } \\
\text { Sciences }\end{array}$ & Master \\
\hline 2015 & $\begin{array}{l}\text { Using Decision Support Systems and Life } \\
\text { Cycle Assessment Approach For } \\
\text { Selecting Wastewater Treatment System }\end{array}$ & $\begin{array}{l}\text { Mustafa } \\
\text { YILDIRIM }\end{array}$ & $\begin{array}{l}\text { Akdeniz } \\
\text { University }\end{array}$ & Science & Doctorate \\
\hline 2015 & $\begin{array}{l}\text { A Decision Support Model Proposal for } \\
\text { Use in Cultural Heritage Management }\end{array}$ & $\begin{array}{l}\text { S. Armağan } \\
\text { GÜLEÇ } \\
\text { KORUMAZ }\end{array}$ & $\begin{array}{l}\text { Selçuk } \\
\text { University }\end{array}$ & Science & Doctorate \\
\hline 2016 & $\begin{array}{l}\text { Credit Evaluation in Banking and } \\
\text { Decision Support Systems }\end{array}$ & $\begin{array}{c}\text { Bucan } \\
\text { TÜRKMEN }\end{array}$ & $\begin{array}{c}\text { Okan } \\
\text { University }\end{array}$ & $\begin{array}{l}\text { Social } \\
\text { Sciences }\end{array}$ & Doctorate \\
\hline 2016 & $\begin{array}{l}\text { Safety Based Decision Support Systems } \\
\text { for Marine Structures }\end{array}$ & $\begin{array}{l}\text { Emre Koray } \\
\text { GENÇSOY }\end{array}$ & $\begin{array}{l}\text { İstanbul } \\
\text { Technical } \\
\text { University }\end{array}$ & Science & Master \\
\hline 2017 & $\begin{array}{c}\text { A Software Library for Computerized } \\
\text { Clinical Health Decision Support System } \\
\text { Focusing on Acoustic Respiratory Data } \\
\text { Acquisition and Analysis }\end{array}$ & $\begin{array}{l}\text { Güneş } \\
\text { HARMAN }\end{array}$ & $\begin{array}{l}\text { İstanbul } \\
\text { University }\end{array}$ & Science & Doctorate \\
\hline 2018 & $\begin{array}{c}\text { A Decision Support System for Crew } \\
\text { Planning }\end{array}$ & $\begin{array}{l}\text { Mehmet } \\
\text { Tankut } \\
\text { TÜRKSEVEN }\end{array}$ & $\begin{array}{l}\text { Çankaya } \\
\text { University }\end{array}$ & $\begin{array}{l}\text { Social } \\
\text { Sciences }\end{array}$ & Master \\
\hline 2018 & $\begin{array}{c}\text { Financial Decision Support Systems in } \\
\text { Business }\end{array}$ & $\begin{array}{l}\text { Hatice } \\
\text { Dervişoğlu } \\
\text { ÇELiK }\end{array}$ & $\begin{array}{l}\text { Bahçeşehir } \\
\text { University }\end{array}$ & $\begin{array}{l}\text { Social } \\
\text { Sciences }\end{array}$ & Master \\
\hline 2018 & $\begin{array}{l}\text { Development of Spatial Decision Support } \\
\text { Systems with Machine Learning } \\
\text { Techniques: Case of Aksaray Province }\end{array}$ & $\begin{array}{l}\text { Süleyman Sefa } \\
\text { BİLGİİOĞLU }\end{array}$ & $\begin{array}{l}\text { Aksaray } \\
\text { University }\end{array}$ & Science & Doctorate \\
\hline
\end{tabular}




\begin{tabular}{|c|c|c|c|c|c|}
\hline 2018 & $\begin{array}{c}\text { Examination of Safranbolu Tannery } \\
\text { Buildings Refunction Process Using with } \\
\text { Decision Support Systems }\end{array}$ & Ömer ÖZEREN & $\begin{array}{l}\text { Selçuk } \\
\text { University }\end{array}$ & Science & Master \\
\hline 2019 & $\begin{array}{c}\text { Analysis of Supplier Selection in Clothing } \\
\text { Plants by the Help of Multi-Criteria } \\
\text { Decision Support Systems }\end{array}$ & $\begin{array}{l}\text { Deniz } \\
\text { KARATAŞ } \\
\text { CEVIZCI }\end{array}$ & $\begin{array}{l}\text { Dokuz Eylül } \\
\text { University }\end{array}$ & Science & Master \\
\hline 2019 & $\begin{array}{l}\text { Data Mining Applications in Decision } \\
\text { Support Systems and an Application } \\
\text { Example in Personnel Selection }\end{array}$ & Fatih DEM & $\begin{array}{l}\text { Marmara } \\
\text { University }\end{array}$ & $\begin{array}{c}\text { Social } \\
\text { Sciences }\end{array}$ & Master \\
\hline 2019 & $\begin{array}{c}\text { Hospital Laboratory Information } \\
\text { Management Additional Decision } \\
\text { Support Systems in the System Taking } \\
\text { Samples Using and Improvement of } \\
\text { Classification }\end{array}$ & $\begin{array}{l}\text { Mustafa } \\
\text { COŞKUN }\end{array}$ & $\begin{array}{l}\text { Akdeniz } \\
\text { University }\end{array}$ & $\begin{array}{l}\text { Health } \\
\text { Sciences }\end{array}$ & Master \\
\hline 2019 & $\begin{array}{l}\text { The Development of Decision Support } \\
\text { Systems for Fire Risk and Danger Maps }\end{array}$ & $\begin{array}{c}\text { Mehmet } \\
\text { BOYATAN }\end{array}$ & $\begin{array}{c}\text { Artvin Çoruh } \\
\text { University }\end{array}$ & Science & Master \\
\hline 2019 & $\begin{array}{l}\text { Development of Optimal Decision } \\
\text { Support System for the Maintenance } \\
\text { Processes of Aircraft Engines }\end{array}$ & $\begin{array}{c}\text { Lilya } \\
\text { UMEROVA }\end{array}$ & $\begin{array}{c}\text { Yildız } \\
\text { Technical } \\
\text { University }\end{array}$ & Science & Master \\
\hline 2019 & $\begin{array}{l}\text { Use of Decision Support Systems in } \\
\text { Warehouse Management and an } \\
\text { Application on Determining Important } \\
\text { Criteria for Product Placement }\end{array}$ & $\begin{array}{l}\text { Mustafa } \\
\text { ARSLAN }\end{array}$ & $\begin{array}{l}\text { Maltepe } \\
\text { University }\end{array}$ & $\begin{array}{c}\text { Social } \\
\text { Sciences }\end{array}$ & Master \\
\hline 2020 & $\begin{array}{l}\text { A Computer Assisted Decision Support } \\
\text { System for Education Planning }\end{array}$ & Yiğit ALİ̧AN & $\begin{array}{c}\text { Munzur } \\
\text { University }\end{array}$ & Science & Master \\
\hline 2020 & $\begin{array}{l}\text { The Use of Artificial Intelligence in } \\
\text { Organizational Decision Support } \\
\text { Systems: Design and Implementation }\end{array}$ & $\begin{array}{c}\text { Mert } \\
\text { DÖNERÇARK }\end{array}$ & $\begin{array}{l}\text { Dokuz Eylül } \\
\text { University }\end{array}$ & $\begin{array}{c}\text { Social } \\
\text { Sciences }\end{array}$ & Master \\
\hline
\end{tabular}

